TP Periodica Polytechnica

Architecture

44(1), pp. 1-8, 2013

DOI: $\underline{10.3311 / P P a r} .7297$

http://www.pp.bme.hu/ar/article/view/7297

Creative Commons Attribution (i)

RESEARCH ARTICLE

\section{Tradition and Liturgy:}

Centralising Tendencies of Lutheran Church Architecture in Hungary during the Interwar Period

Eszter Baku

RECEIVED 7 DECEMBER 2012

\section{Abstract}

The majority of the architectural research focusing on Hungarian architecture in the Interwar period, has to date, mainly analysed buildings with regard to international modern architecture and the steps leading to the development of modern church architecture. This research has however, only marginally expanded to include Evangelical Lutheran church architecture. The present article undertakes a complex research on a special building type, which increased between the World Wars and was determined by a geometric centralised ground plan based on both national and international architectural tradition. Lutheran churches built between the World Wars with central ground plans are analysed from both a liturgical perspective, examining the theological aspect and the use of space, and also from the tradition of the ground plans.

\section{Keywords}

Centralised space $\cdot$ church architecture $\cdot$ Lutheran churches - liturgy $\cdot$ architecture in the Interwar period

\section{Eszter Baku}

Department for History of Architecture and of Monuments, Budapest University of Technology and Economics,

Müegyetem rkp. 3-9., H-1111 Budapest, Hungary e-mail: bakueszter@gmail.com

\section{Introduction}

Architecture and church architecture of the Interwar period might be apostrophised as the investigation of solutions. As Károly Hafenscher wrote: "The huge wave of church building of the century (of its first third and its last decade) has simultaneously borne the traditional practice and the openness towards novelty. These periods have been described as the search for identity, the conservation and re-composition of 'Lutheran' values in a different context." [4, p. 16.] The church building wave, almost regardless of denomination, is in connection with historical, economic and political events. It means that because of the trauma of World War I and despite the burden of the Great Depression, the volume of church building had increased in Hungary after the 1920s and lasted until the 1940s. Gyula Sándy, the frequently employed Lutheran architect, also refers to the process: "Conclusions of great Wars motivated the faithful souls by vivid activity in the field of ecclesiastical life. [...] Far from the War-years, the activity of believers decreased; until the end of the $19^{\text {th }}$ century and the beginning of the $20^{\text {th }}$ century, new church constructions could hardly be found until World War I, when, in spite of the critical economic situation, more churches were built in Hungary in 10-15 years than one century before." [16, p. 459] The increased number of Lutheran churches between the Wars was characteristically varied in both style and the applied structures of the ground plans. Although less Protestant churches were built than Roman Catholic ones, both were characteristic in the pluralism of styles. In this case, pluralism of styles refers to historical styles that became a coulisse-like character using modern building materials that coexisted together with the marks of style of modern architecture, with the adaptation of foreign architectural influences such as reinforced concrete. In the present article, a survey is made of the churches with a central ordering space, the centralising tendencies of the Lutheran Church and church buildings are researched, and completed with the adaptation of possible foreign results. Churches with a central ground-plan arrangement could be another possibility for the renewal of church buildings in this period. 


\section{Roots of the central arrangement churches The foreign origin}

Lutheran churches with central arrangement space structure in the Interwar period in Hungary were not without precedent either in Hungarian or European architectural history. Centralising tendencies in Protestant church architecture need to briefly be reviewed to see distinctly the preliminary of the form and the tradition, on which $20^{\text {th }}$ century churches were referred to, and the measures, which appointed the direction of how to plan and build Lutheran churches.

Four elements organized the space and ground plan of Protestant churches: the liturgy, the pulpit, the position of the Lords' Supper, the altar and their connection to the congregation. These aspects significantly influenced the form of the space and already evoke the need of central ground-plan arrangement churches, because the form decreased in a longitudinal direction and increased transversely. [3, p. 170] Churches with centralising ground plans had spread all around Europe and finally reached Hungary through various routes. The centralised ground plan forms originated from the French Huguenot architecture [14, p. 117] [9, p. 79] [7, p. 190] and could be explained by the gesture of reaching back to the ancient central church types and the simplicity of the early Church. [13, p. 205] The term 'temple' of the Huguenots implies in its name, a hint to the Biblical predecessor, the Temple of Jerusalem. Research indicates a different approach to centralising tendencies, at the beginning of the 18th century, from Germany based on the oeuvre of the Protestant church architecture theoretician, architect, and mathematician Leonhard Christoph Sturm. [14, p. 117] In 1712, and later in 1718 [19] he published a theoretical analysis of Protestant church architecture in which he made a collection and a typology of those church plans he found suitable for Protestant churches. [9, p. 80][3, p. 172] The Protestant model plans [9, p. 80] of Sturm determined the centralised Lutheran churches for centuries. The adaptation of Sturm's ideal ground plans was manifested in 20th century Hungarian Lutheran church architecture. [21, pp. 364-365]

\section{From the 'Eisenach Directive' to World War I}

Besides the effects mentioned above, various measures and regulations affected Lutheran church design, for example the 'Eisenach Directive'. In 1861, one of the 16 articles of the 'Eisenach Directive' adopted by the Lutheran Regional Churches in Germany, under the influence primarily of the completion of Cologne Cathedral in the late-Gothic style, decreed: "the dignity of Christian ecclesiastical architecture requires a connection with one of the historically developed Christian architectural styles and, taking as the basic form the longitudinal rectangle, recommends especially the style called Germanic (Gothic) alongside the early Christian basilica and the style known as Romanesque (pre-gothic)." [17, p. 7] After the 'Eisenach Directive', churches with centrally arranged ground plans were no longer suitable for Protestant churches because of the relationship to the profane architecture. Instead of the various, centralised churches, the new regulations of the Directive re-evaluated the medieval architecture [14, p. 122] and supported the building practice of the longitudinal, orientated churches provided with tower and apse. [6, p. 21] The centralised forms were ignored because of the reminiscence of theatres or antique sanctuaries, although the reasons that had evoked its application remained. The centralised arrangement consequently evolved from the requirements of the Protestant liturgy. However, these could not be applied in the same way. [14, p. 162] In the last decades of the $19^{\text {th }}$ century, the 'Eisenach Directive' had lost its strength, which led to the development of new programmes like the Wiesbaden Programme in 1891 and the 1st EvangelicalLutheran Congress of Church Architecture held in Berlin in 1894. These processes were based on the Liturgical Movements, which laid emphasis on the theological aspects. As a result, the inner space of the church had to be formed. Understandably, World War I set these processes back; however a group of talented young architects had consciously been preparing for the transformation of spaces and church forms, according to the new concepts, and to create a liturgy-centred inner space. During the War, these
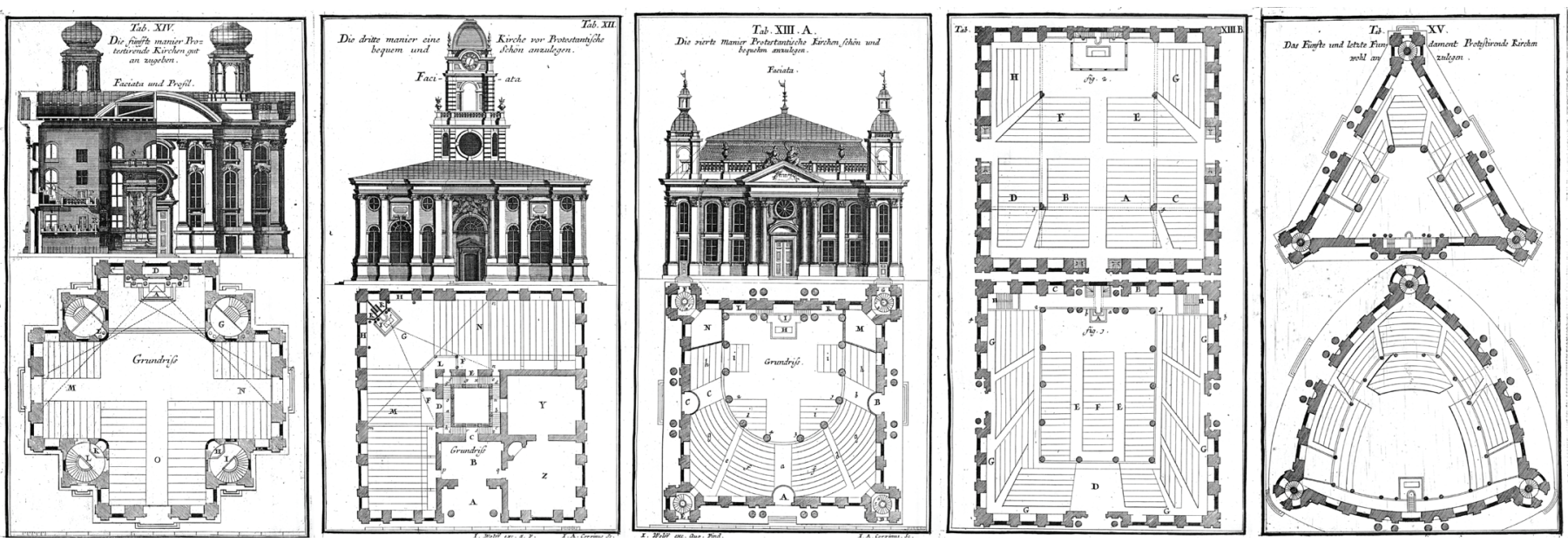

Fig. 1. Central and centralising ground-plans of L.C. Sturm (plates XIV., XII., XIII. a, b, XV.) [19] 
concepts were perfected, and as a result, were manifested in the work of Otto Bartning Vom neuen Kirchenbau (1919) or in the churches of Dominicus Böhm from the late 1910s. [17, p. 15]

\section{Theology, liturgy and practice}

The most important aspect and challenge of the Evangelical religious service was to make the principal parts of the liturgy visible. Namely, the priest has to be clearly visible and audible, and the congregation needs to be closer to the altar and the pulpit [3, p. 170], whereby they can take part in both the sermon [13, p. 133] and the Lord's Supper. In the case of Protestant church planning, the fundamental liturgical rules need to be taken into consideration. These rules can prevail in different types of churches; in a short, aisleless/single-nave church building that consists of a single halllike room without columns, or in centralised arrangements - even polygons, Greek-cross etc. [16, p. 462]. In many cases, the shape, the size and the arrangement of the plot affected the ground-plans of the churches, because "a building plot with special, irregular form without right angles and parallel sides could motivate a polygonal church form that is able to better fit into its environment like: hexagon, octagon and, moreover, triangular, trapezoid or circular ground plans." [16, p. 463] - wrote Gyula Sándy.

Several factors influenced the liturgical efforts and church building practice (determined by the liturgy) from the second part of the $19^{\text {th }}$ century to the first part of the $20^{\text {th }}$ century. From a Central European perspective, we can see that the most frequent area of the church building principles was that of the German Protestant provinces. Architecturally, during the second part of the $19^{\text {th }}$ century, it was the perfection of the German neo-Gothic style (i.e. the national style). Principles were elaborated during the Congress of Evangelical Regional Churches in Germany in Eisenach (first held in 1846, and regularly from 1852), and later summarised and published in 1861 as the "Eisenach Directive" (Eisenach Directive on Lutheran ecclesiastical architecture/Regulativs für den Evangelischen Kirchenbau). According to the Directive's principles, the church buildings had to be orientated, built with a longitudinal

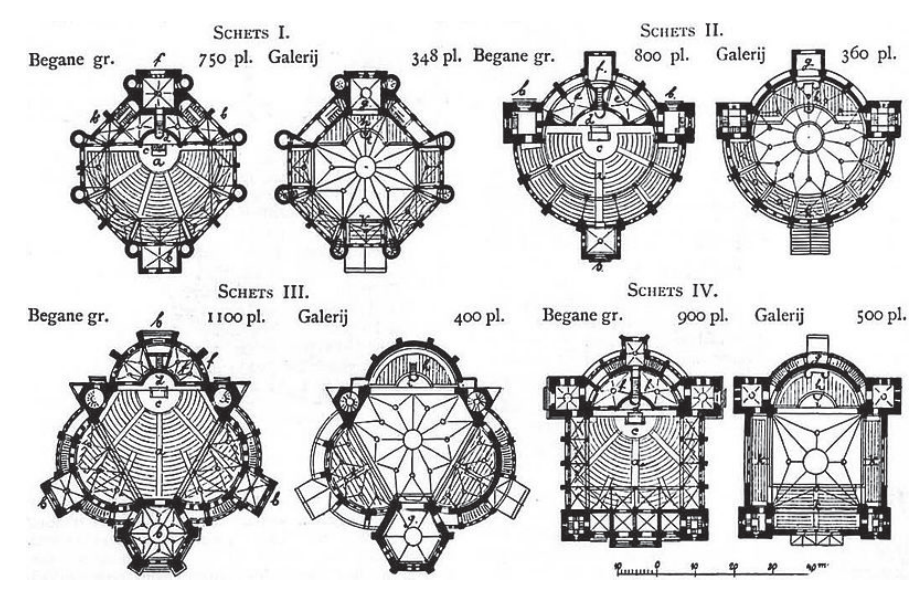

Fig. 2. Johannes Otzen's alternative plans according to Wiesbaden Programme. [10] quadrangle ground plan in historical "Christian style" with a main front tower, a main entrance, with raised sanctuary where the altar is placed in front of the back-wall, and with a pulpit, which must be placed to the arch separating the nave and the sanctuary. The long-lasting influence of the church building rules registered in the "Eisenach Directive" is perceivable in Hungarian Evangelical church architecture. Gyula Sándy's churches in Hungary, from the first part of the $20^{\text {th }}$ century, could be considered to exemplify the rules of the Directive. [8, pp. 18-19].

After reviewing the liturgical references and the various types of the Agenda, we should conclude that in these documents, no architectural determination regarding the real function of the church buildings, the use of space in accordance with the liturgy can be found. The former rich Evangelical liturgy, originated from the Medieval Roman liturgy after omitting the parts of the offertorium and the canon missae, which was created in the 16th century, was simplified in the $19^{\text {th }}$ century. Through the liturgical works of the 1930s (as the Agenda of Bishop Sándor Raffay and doctoral thesis of theologian Professor Lajos Jánossy), an intention - which is a part of a process - was formed and directed to reaching back to the beginning, the 16 th century rich and synthetic liturgy. In 1944, a general work called Evangelical Churches was published, in which Jánossy wrote a whole chapter about "The Character and the Purpose of the Evangelical Church Building". He argued that in addition to returning to the previous liturgical order, a Medieval styled, orientated church with longitudinal axis, divided with an arch would be suitable in the same manner as urged by the "Eisenach Directive". The formerly mentioned fact correctly characterised the conservatism of the given era, and thus explains the Medieval-styled architectural character of Gyula Sándy and Bálint Szeghalmy. In the Evangelical church architecture, the formerly preferable pulpit altars were slowly discarded between the World Wars because of the remaining principles of the Directive and also the recently appeared conservatism of liturgical education. Practical causes also supported this process, as the lower sized pulpit was suitable for effective sermons. The pulpit usually faced the altar and was placed to its "evangelical side".

The principles of the "Eisenach Directive" defined by conservative Lutheran theology, had to be suitable for the German Protestant Church, which included the unified Lutheran and Calvinist tendencies in Germany. This "archaising tendency" was less acceptable for the Calvinists, for those who followed the theological principles of the enlightenment and for those who preserved the traditions of the $18^{\text {th }}$ century. These processes were represented by the "Wiesbaden Programme/Wiesbadener Programm", which was an unofficial but a much more accepted norm in 1891. It was conceptualised by the priest Emil Veesenmeyer and the architect Johann Otzen. The first example of the Programme was Otzen's Ringkirche in Wiesbaden.

According to the Programme, the Protestant church was similar to an assembly room from which the formerly enforced Catholic character was discarded; consequently, the uniformly 
treated interior - without separate sanctuary - signified the unity of the congregation. In this interior, the pulpit was equal with the altar that was placed behind it, and in the middle of the congregation space, the members of the convention could partake in the Lord's Supper.

Hungarian Calvinist church architecture was more affected by this Programme than the Lutheran's. Therefore, Frigyes Schulek's Calvinist church in Szeged (built between 1882-84) had a special significance and novelty before the Wiesbaden Programme. He intended to suggest the emphasis of the pulpit, to remove the communion table from the sanctuary to the middle of the church with the abandoning of the apse. He published his church-building principles in his essay. [18, pp. 11, 18, 25]

From the end of the $19 \mathrm{t}^{\mathrm{h}}$ century to the beginning of the 20th century, a unique architectural solution occurred in Hungary, in the case of longitudinal-, and central-arrangement churches, when the reticulated piers were taken into the inner space thus creating a "reduced side-aisle". Applying these principles, a possibility appeared to dissolve the confining rules of the Eisenach Directive regarding the galleries, as using a reduced side-aisle did not break the unity of the space by creating a functional solution. [14, p. 123] Outstanding examples can be found in Hungary in the oeuvre of Samu Pecz, in a Calvinist church plan from 1888 or a Calvinist church in Budapest, in Szilágyi Dezső square where the aisle was supplemented by the function of a corridor. [14, p. 123] Although Gyula Sándy did not mention the terminology of reduced sideaisle, in the case of planning Lutheran churches, he suggested a similar solution system for expanding the capacity of churches and for solving the corridor between the rows of seats. [16, p. 463] Following on from this train of thought, it became apparent that the Wiesbaden Programme primarily corresponded to the requirements of the Calvinists in spite of its declared Protestant character. The planning practice, in general, compromised between the principles of the Eisenach Directive and the Wiesbaden Programme, responding to the question of the retaining space of the sanctuary: in case of centrally arranged Evangelical churches, a separate apse was designed. The idea of a complete-centralising plan was raised by Christian Runk at the $1^{\text {st }}$ Evangelical-Lutheran Congress of Church Architecture held in Berlin in 1894. "The altar must be placed at the centre of the church, not just symbolically, but in fact." [17, p. 9] His concept increasingly drew support in the $20^{\text {th }}$ century in Germany, $[17$, p. 9] and manifested, between the World Wars, such buildings as found in the plan of Otto Bartning's Starchurch from 1922. In the first part of the $20^{\text {th }}$ century, the idea of a complete-centralising plan and its discourse did not become significantly determining either in theory or in the practice in Hungary.

\section{Lutheran churches with centralised ground-plan between the World Wars}

Despite World War I and the Great Depression, numerous Lutheran churches were built in Hungary during the Interwar period. From 1920 to 1945 , more than 70 new Lutheran churches, or churches used by both Lutherans and Calvinists, were constructed, and 20 of these were created in the capital and its surroundings. Most of the churches show longitudinal arrangement; nevertheless, the old/new approach of centralising tendencies strongly emerged. During the researched period, 11 churches were built with a number of centralised ground plans using various methods, structures for covering the space, and naturally, in various styles. Churches with a centralised ground plan had appeared after a 25-year caesura, which showed an unswerving purpose of both the architects and the community. Numerous propositions can explain the diffusion of centralised churches in Hungary between the World Wars; German models have a distinguished role, also the expanding Roman Catholic liturgical movement and the organizing work of the Churches after the War, however, significantly, the new construction materials would have been beneficial to the wide distribution of this church type. The use of reinforced concrete, new structures and vaulting possibilities was able to spread into church architecture.

\section{The typology of central ground plans}

The main effort of Lutheran churches is to place the pulpit and the altar closer to each other and to the believers. Therefore the "main task to solve the centralisation of the inner space, is the most important architectural, interior-designer problem of planning Lutheran churches up to the present day." [2, p. 18] Since in Lutheran churches, the altar is placed opposite the main entrance, a longitudinal axis could be drawn between them. In a geometric sense, the central-ground plan churches have subtypes as round, elliptical, Greek-cross or even-sided regular polygon (square, hexagon or octagon) and odd-sided regular polygon (triangle and pentagon). After Sturm, we can also add centralising ground plans like $\mathrm{T}$ or L-shaped churches that make approaches to centralised space structures. Unfortunately, it is difficult to explain where the centralised ground plan churches originated, but we suppose that the symbolism and the economical building structures were examples of the architectural principles in Lutheran churches.

\section{Lutheran Greek-cross ground-plan churches}

The Greek-cross form is frequently encountered in Lutheran church architecture, because it is less characteristic of the multiple-used Lutheran-Calvinist churches, where the hexagon ground plan was preferred. The Greek-cross groundplan churches were built between the World Wars, supplemented with rich symbolical meaning and deeply rooted in the Lutheran traditions. The plan type followed the sequence of the antecedent types indicated by János Krähling and Gergely Domonkos Nagy in their survey. [9] Thus we can assume that the direct antecedents of the Greek-cross church type during the Interwar-period were the churches remaining from the 
Hungarian Baroque style. Conversely, the indirect antecedents were the Huguenot architecture, the North-European examples from Scandinavia, the Silesian timber churches and Sturm's plans. [9, p. 1] Although the location of the pulpit is slightly problematic because of the direct visibility, Sturm mentioned this type - as a suitable arrangement for Lutheran churches - in his second work in 1718. The pulpit was usually arranged in front of the crossing pillar; nevertheless, the attempt at perfect visibility could not be produced. [14, p. 118] In Lutheran churches, the altar was set in the apse or before the wall, consequently the altar could not be placed in the geometrical centre of the Greek-cross. In his essay about Protestant church architecture, Samu Pecz provided a historical and architectural analysis, in which his third group was given to the Greekcross type. He mentioned that efforts had been made to build galleries on every side of the cross but it was inconvenient. Therefore, by building galleries on just the lateral side of the cross, this ground-plan type began to progress in a more functional direction, thus becoming a more suitable ground plan for Lutheran churches. [11, p. 245] A few Greek-cross groundplan Lutheran churches had such an arrangement in Késmárk (1717), Maglód (1776) and Domony (1777), nevertheless these were built before Pecz's recommendation, so we can assume that this process had naturally changed regarding the usage. In these spaces, the galleries were built on the lateral sides of the church while the organ gallery was placed in front of the altar. Until the 19th century, numerous Lutheran churches were built with the Greek-cross ground plan (for example: in Békéscsaba the Kistemplom after the enlargement, Besztercebánya, Kassa/ Kosice, Igló/Spišská Nová Ves and Miskolc). Around the turn of the century, this process seemed to have decelerated. After constructing the church of Miklós Ybl in Kecskemét (1863), the Slovak Lutheran church in Budapest (1867) and the Lutheran church in Diósgyőr (1902), the Greek-cross layout reappeared in 1929 in Kaposvár. In order to examine the diffusion of the ground plan, we should also take the iconological meaning of the cross into consideration. After World War I, special significance was assigned to the meaning of the cross; therefore, the Death of Christ, Salvation from Sins and centrality as a collaboration holding the community together by faith, became more important. In the Interwar period, a new community church type, [6, p. 26] which unified the functions of the church and the community centre, was developed to satisfy these demands. We could suppose that the preliminary of this type was the plan of Sturm's L-shape ground-plan church, which was published in various versions supplemented with a parish building, community hall or a library. [6, p. 26] Three churches by Gyula Sándy adopted Sturm's concept but with the Greekcross ground plan and semicircular apse (These were built in Kapsovár (1929), Diósgyőr-Vasgyár (1936-38) and GyőrNádorváros (1940)). The architect merged the functions by creating a complex church building in the case of Diósgyör and Györ, as the building of the churches also included the community hall.

\section{Lutheran churches with regular polygon ground plans}

Churches with polygonal ground plans were widespread among Lutherans between the World Wars. Depending on the number of the sides, we should distinguish subtypes as square, hexagon or octagon, which are all suitable for Lutheran temples. According to the Lutheran liturgy, the hexagonal and octagonal forms were spread. Although Lutheran churches were mainly built with a regular polygon arrangement and Calvinist churches applied odd polygon ground-plans, the Lutheran-Calvinist temples were usually constructed as triangular or octagonal forms; Sturm also mentioned the triangular form, emphasising its difficulties. [19, p. 39] Johannes Otzen had similarly researched the perfectly suitable ground plans for Lutheran churches in accordance with the Wiesbaden Programme in 1891. His plans were based on centralising structures, such as the circle, triangle, square or Greek-cross, - supplemented by towers or semicircular extensions. The goal of these plans was to solve the difficulties of seeing and hearing, therefore the pews were organised in concentric circles with the altar as the focus. Samu Pecz recommended regular polygon ground plans for Lutheran churches because of the arrangement whereby the apse can be placed opposite the entrance. [11, p. 212] Consequently, in regular polygon churches, one side of the polygon

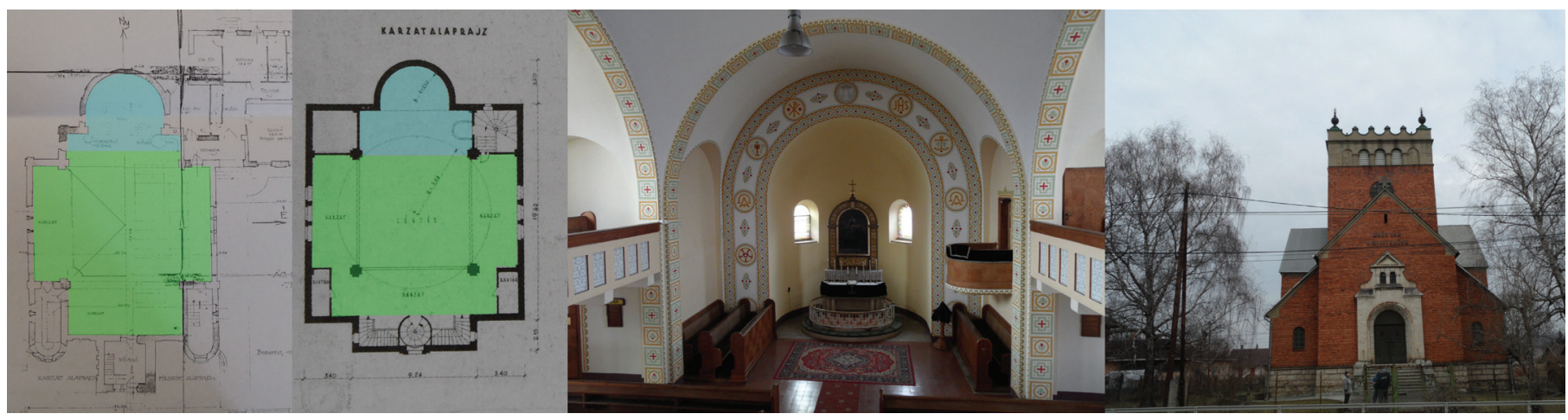

Fig. 3. Greek-cross ground-plans of Kaposvár and Diósgyőr-Vasgyár 
- where the entrance can be placed - must be opposite another side, where the sanctuary can be placed. In contradiction to the arrangement of the regular polygon, in an odd polygon arrangement, an angle must be found that would be suitable for placing the pulpit; thus, Pecz recommended the square and pentagon for Calvinists but regular polygons for Roman Catholics and Lutherans. [11, p. 134] Sturm illustrated three methods of how to build the interior of a square as the simplest even-sided regular polygon. [19, p. 178] During the Interwar period in Hungary, two Lutheran churches, both constructed on the outskirts of the capital, were built with a square-form ground plan. The role of the urban peripheries became more important after World War I because a significant number of inhabitants had settled down in these areas, which resulted in a huge number of church buildings. Gyula Sándy built more than ten Lutheran churches around the capital, of which, the one in Rákosszentmihály (1933-34) has a square-form floor plan. György László and Jenö Szalkai designed a centralised-ordering church with an exceptional dome in Rákospalota (1936-1941).

Above the central space of the church, there is a reinforced concrete hemispherical dome with a lantern, which bares resemblance to the Renaissance domes, although the applied materials and the construction of the long, narrow windows suggests a knowledge of the principles of modern architecture. Although the structure of a dome sitting on a square shape is an unusual solution for Lutheran churches, the form, which is based on the Roman Catholic traditions, could represent the gathered community in a monumental and solemn method. [5, p. 216] A feature of the dome with its diameter of $14 \mathrm{~m}$ is the 6-cm thick reinforced concrete shell - emphasized by the 105-year-old architect while recalling the remarkable structure of the church. [1, pp. 3-4]

Among the churches built with polygonal floor plans in the given era, the hexagonal and octagonal types are outstanding. Most of them are connected to the architect Bálint Szeghalmy who designed three churches for Lutheran-Calvinist multiple use (Sümeg (1936-37), Hévíz (1937-39) and Mersevat (1941)).
Another church was built with the similar centralised ordering in Gödöllő (1929-32) by Frigyes Hetzel. We should consider that between the World Wars, regular polygon hexagonal and octagonal forms were characteristically adapted to LutheranCalvinist churches, because the ground plan was almost entirely suitable for both liturgical regulations and was also easily convertible.

\section{Lutheran churches with round and oval ground-plans}

The use of the elliptic form, in the case of Lutheran churches, originated from Switzerland in the 17th century and was diffused into German territories in the 18th century. Sturm had a special role in the diffusion of round and elliptical ground plans, even though in German areas its prevalence can be traced back to the age of Classicism when numerous Roman Catholic churches were built using a domed rotunda form. [14, p. 119] According to Samu Pecz's typology, the third group was dedicated to the round and polygonal shaped temples in which the space was extended by galleries and the altar was placed in front of the gallery or in the sanctuary built for this purpose.

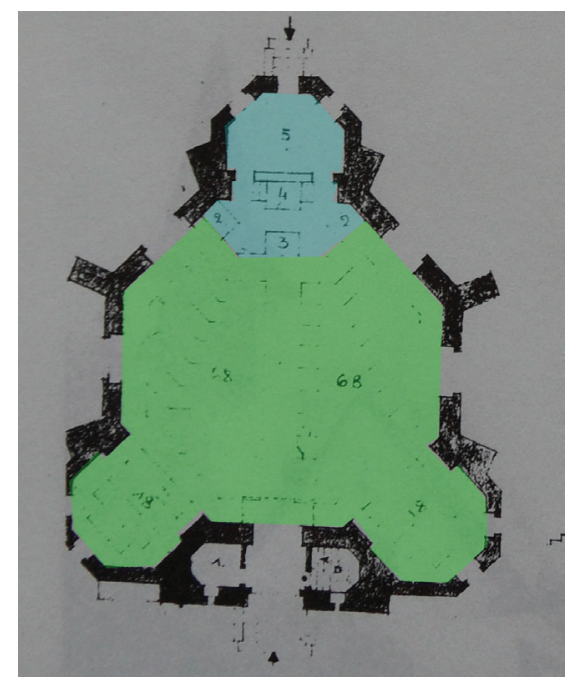

Fig. 5. Protestant church in Hévíz.
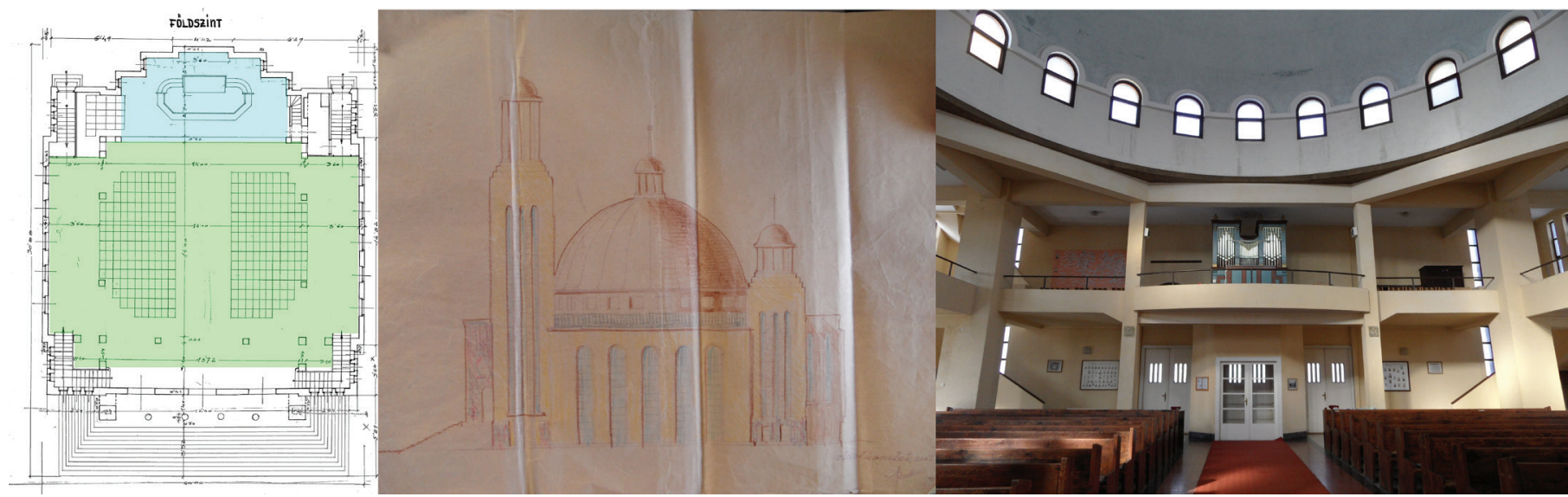

Fig. 4. Evangelical church in Rákospalota (Budapest). 
[11, p. 244] Lóránd Friedrich classified the churches with round or elliptical floor plans as inappropriate for Lutheran churches, $[3$, p. 173] nevertheless, examples that are supposed to have had German influence (the oeuvre of Sturm and Otto Bartning) can be found in Hungary during the Interwar period. We can not find examples in Hungary that followed Otto Bartning's Starchurch that was built in a perfect centralising spirit by placing the altar in the centre of the interior. Therefore, Hungarian Lutheran churches could not manage the perfect centralisation through the unifying of the geometrical and the liturgical centre. We can barely find the preliminaries of the round and oval ground-plan forms in Hungary, but in German areas these were much more prevalent. Among the Hungarian examples, Lajos Kimnach's plan in Sopron (1783), [20, p. 43] was followed by the Lutheran church of Kassa/Kosice (1804). On the first plan, the enormous elliptical space is supplemented by galleries and covered by a huge dome, while the plan from Kosice also showed an elliptic plan, which was extended to a Greek-cross form and again covered with a dome. During the Interwar period, two Lutheran churches were built with round-shaped centralised ordering. In 1929, János Frecska's awarded plan for the architectural competition for a Lutheran church and apartment blocks in Köbánya, was built as a round-shaped church in a modern architectural style. Afterwards, the type was followed by Pál Szontágh's Lutheran church in Borsodnádasd-Lemezgyártelep (1934) where a centralised plan with a completly round arrangement supplemented by an apse and an entrance hall was established.

\section{Summary}

Although the longitudinal arrangement could be seen as common and also widespread among Lutheran churches, overall we can state that the propensity - that was aimed at the longitudinal arrangement in Lutheran churches from the second half of the 19th century - was clearly broken between the World Wars. After World War I centralised ordering among Lutheran churches appeared more frequently due to the expansion of modern architecture; the application of reinforced concrete; the new methods of covering spaces and the effects of the new liturgical movements. Centralising tendencies were important after the War because of the symbolic meaning that referred to the strong cohesion between the members of the community and the congregation of the Lutheran and also of the Roman Catholic Church. We can also state that the prevalence of the centralising ordering in Hungary (also among the Lutheran and the Roman Catholic Church) was affected by the adaption of the German models and those events particularly

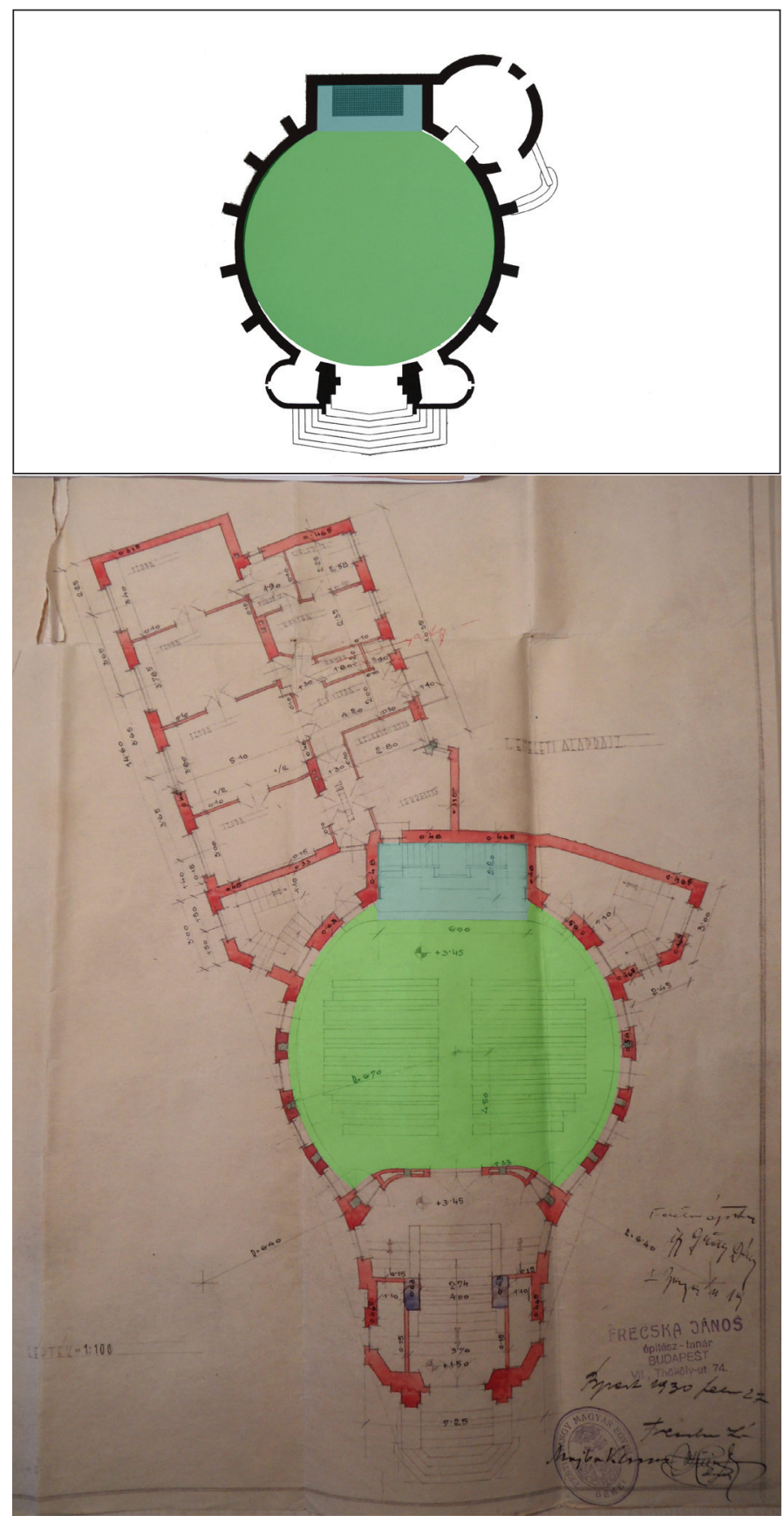

Fig. 6. Lutheran churches in Borsodnádasd and in Köbánya (Budapest)

dealing with church architecture. For example, the 3rd Congress of Lutheran Church Architecture, organised in Magdeburg, pointed out that: "The centralising church is the most expressive form for the Lutheran church building; it is the most abstract interior. [... ] The centralising interior is the most powerful symbol of the eschatological belief in the world to come." [17, p. 37]

\section{Acknowledgements}

The work reported in the paper has been developed in the framework of the project. "Talent care and cultivation in the scientific workshops of BME" project. This project is supported by the grant TÁMOP 4.2.2.B-10/1-2010-0009 


\section{References}

1 Cs. Kiss É., Aki látta épülni Budapestet: mindig izgatott a vasbetonszerkezetek szépsége - mondja a 105 éves László György épitész. Budapesti Negyed, 49-50(3-4) (2005).

2 Foltin B., Az evangélikus templom. in 'Evangélikus templomok Magyarországon' pp. 19.

3 Friedrich L., A Magyar evangélikus templom fejlödése az újkorban. in 'Evangélikus templomok (eds: Kemény L., Gyimesi K.)’ Athenaeum, Budapest (1944).

4 Hafenscher K., Mégis, kinek a háza? in 'Új evangélikus templomok (eds.: Krähling J., Vukoszávlyev Z.)’ Luther kiadó, Budapest, 11-20 (2008).

5 Kemény L., Gyimesi K., Evangélikus templomok, Athenaeum, Budapest (1944)

6 Krähling J., A 20. századi magyarországi evangélikus templomépitészet a rendszerváltozásig. in 'Új evangélikus templomok (eds.: Krähling J., Vukoszávlyev Z.)' Luther kiadó, Budapest, 21-28 (2008).

7 Krähling J., Adalékok a hugenotta imaháztípus magyarországi elterjedéséhez - a Charenton-tipus. Müemlékvédelem, 53(4), 190-196 (2009).

8 Krähling J., Evangélikus templomok a mai Magyarországon (Veszendö templomaink III.). Nemzeti Tankönyvkiadó, Budapest (2004).

9 Krähling, J., Nagy, G. D., Late baroque greek-cross plan type Lutheran churches in Hungary. Periodica Polytechnica Architecture, 40(2), 77-86 (2009).

DOI: $\underline{10.3311 / \text { pp.ar.2009-2.04 }}$

10 Otzen J., Central arrangement plans. De Opmerker, 37, p. 299 (12.09.1891)

11 Pecz S., A protestáns templomok épitéséröl, kapcsolatban a debreceni kálvinista új templom részletes ismertetésével. Pesti Lloyd Nyomda, Budapest (1888).

12 Pröhle S., A templomalap javára. Evangélikus Élet, 4/49, p. 374 (13.12.1936)
13 Raymond A., Menzer Jr., The Reformed Churches of France and the Visual Arts, Seeing Beyond the Word. in'Visual Arts and the Calvinist Tradition (ed.: Corby F. P.), William B. Eerdmans Publishing Co., Canada (1999).

14 Róka E., Pecz Samu Szilágyi Dezső téri református temploma és a protestáns centralizáló templomépitészeti hagyomány. Ars Hungarica, 24(2), 117-175 (1996).

15 Róka E., Centralizáló törekvések a protestáns templomépitészetben, Európa és Magyarország, 16-19 század. Utóirat, 8(5), 11 (2008).

16 Sándy Gy., A templomépitések gyakorlati megvalósitása. in 'Evangélikus templomok (Kemény L., Gyimesi K. eds.)' Athenaeum, Budapest, 459-472 (1944).

17 Schnell H., Twentieth Century Church Architecture in Germany: Documentation, Presentation, Interpretation. Verlag Schnell \& Steiner, Munich, Zurich (1974).

18 Schulek F., A református templom. Építési Ipar, 9 (04.01.1885).

19 Sturm L. C., Vollständige Anweisung alle Arten von Kirchenwohl anzugeben (1718).

20 Winkler G., Épitészettörténeti áttekintés. in 'Evangélikus templomok Magyarországon (Dercsényi B., Foltin B., G. Györffy K., Hegyi G., Winkler G., Zászkaliczky Zs. eds.)' Hegyi \& Társa Kiadó, Budapest, 27-45 (1992).

21 Vukoszávlyev Z., Unifying the Community: The Evolution of Centralized Space in Hungarian Church Architecture 1900-2010. in 'Proceedings of the 2nd International Conference of the European Architectural History Network (eds.: Heynen H., Gosseye J.), Koninklijke Vlaamse Academie van Belgie voor Wetenschappen en Kunsten Brussel, 364-365 (2012).

22 -, V.Z monogrammal, A templomalap javára. Evangélikus Élet, 4/50, $382(20.12 .1936)$. 